\title{
LOAN MORATORIUM 2020- ITS IMPACT ON INDIAN BANKS
}

\author{
Dr. Meera Mehta \\ Assistant Professor, Dept. of Commerce \\ SBS College, Delhi University, India \\ E-mail: meeramehta17@gmail.com \\ Rishab Kaul \\ Student, School of Electronics Engineering \\ Vellore Institute of Technology, Vellore, India \\ E-mail: rishabkaul2012@gmail.com
}

\begin{abstract}
Moratoriums area period of temporary suspension of an activity or law till a decision to lift the suspension is made, as in the case of the issues that led to the moratorium are resolved. Moratoriums may be imposed by regulators, by a business, or by the government. A moratorium is often ordered in response to situations of crisis. Moratoriums are not new to the Indian banking sector and have been granted and imposed in multiple instances in the last 20 years. Since 1999 moratoriums have been imposed on 9 banks for various reasons. Recently, a sixmonth moratorium was offered by the Reserve Bank of India (RBI) between March 1, 2020, and August 31, 2020, on all loan equated monthly instalments, to help lessen the troubles faced by the borrowers due to the COVID-19 pandemic. This paper aims to study the recently granted moratorium by the RBI to assess and predict its impact on the banking sector. The study will also reflect on similar instances of moratoriums that have been granted in the United States, Greece, and Thailand in the last 20 years.
\end{abstract}

Keywords: Moratorium, Suspension, RBI, Borrowers, Pandemic.

JEL Classification Codes: E5, E58, E59

\section{INTRODUCTION}

On 27th March 2020, the RBI announced a moratorium on loans by financial institutions in response to the countrywide lockdown declared on 23rd March 2020 which had a triggering effect on the financial condition of the people of the country. A moratorium is a temporary suspension or deferring of activity until further consideration calls for a lift on the suspension, or till the time the issues that led to the moratorium are resolved. Moratoriums may be imposed by regulators, by a business, or by the government. A moratorium is often ordered in response to situations of crisis. For example, in the aftermath of floods, earthquakes, droughts, disease outbreaks, a moratorium may be granted on some financial activities by the central bank or the government. A moratorium period is a time during a loan term when the borrower does not need to make any payments towards the loan. A Moratorium is only a deferment of payment and is different from a waiver. 
Moratoriums are not new to the Indian banking sector and have been granted in multiple instances in the last 20 years. Since 1999, moratoriums have also been imposed on Yes Bank, Global Trust Bank, United Western Bank Ltd., Sikkim Bank Ltd., Bareilly Corporation Bank Ltd., South Gujarat Local Area Bank Ltd., Benares State Bank Ltd., Nedungadi Bank, and Ganesh Bank of Kurundwad Ltd. for numerous reasons.

The focus of this paper is the six-month moratorium offered by the Reserve Bank of India (RBI) between March 1, 2020, and August 31, 2020, on all loan equated monthly instalments (EMIs) to help lessen the troubles faced by borrowers due to the COVID-19 pandemic. For this purpose, all co-operative banks, commercial banks, All-India Financial Institutions, and NBFCs were allowed to grant a moratorium of three months for all term loans on payment of all the instalments that fell between the period. The period was however extended by three additional months, up to August 31, 2020.

\section{Objectives}

This paper focuses on assessing and predicting the impact of the past and recent (moratorium 2020) RBI moratorium on the banking sector in India, with the objectives:

- Understanding the 2020 Moratorium announced by RBI

- Evaluating and predicting the impact of the moratorium on the banking sector in India (in terms of NPAs, CRAR, bank credit, and the profitability ratios).

- Analysing the implications of the Interest on Interest waiver granted and the effects of a complete waiver of interest.

- Understanding the instances of moratoriums around the world, in particular, the USA, Greece, and Thailand

\section{LITERATURE SURVEY}

Imai (2016) stated that, technically, the Japanese debt moratorium legislation could have mitigated the credit crisis for small and medium-sized businesses, but it became more difficult to determine the extent of the financial troubles in small banks. It undermined market discipline and encouraged moral hazard problems. Further, it set up a financial system in which zombie companies appear to flourish, much as the strategy of forbearance did in the 1990s. This has also contributed to slow productivity growth in Japan. Also, it indicated to financial markets that the political pressures to bail out zombie businesses remained strong in Japan. As a result, Japan's response to the financial crisis in the form of the Debt moratorium was generally viewed as a failure.

Arito (2017) examined the effect of Japan's debt forbearance policies on small and medium-sized enterprises (SMEs) as set out by the "Act on Temporary Steps to Promote Funding for Small and Medium-sized Enterprises." Using specific Japanese company survey results, that had received "financing" (e.g. by deferring repayments) and firms that had received "debt forgiveness" (e.g. through reduced interest and/or principal), the paper analysed the determinants and effects of debt forbearance. They found that banks prefer debt redemption for companies that are more profitable and creditworthy, which was found to be consistent with the debt overhang theory.

Mukherjee, Subramanian, and Tantri (2014) offered proof of both the drawbacks and benefits of the debt moratorium under the 2008 Indian Debt Waiver Program. They use data of the loan account of agricultural borrowers and exploit the exogenous rainfall fluctuations for dividing beneficiaries into non-distressed and distressed borrowers. By alleviating debt-overhang 
issues, the waiver leads to significant changes in the loan performers of creditors in distress. However, in keeping with the moral hazard, the waiver had little bearing on the performance of loans by non-distressed creditors but non-distressed borrowers suffered from credit rationing after the waiver. Although banks' over-all non-performing assets declined after the waiver, agricultural non-performing assets rose.

Arslanalp and Henry (2005) asserted that as developing countries had announced debt reduction negotiations through the Brady Scheme, the stock markets of those countries rose by $60 \%$ on average in real dollars terms which was an increase in shareholder value of $\$ 42$ billion. There was no significant increase in the stock markets of the countries within the group that did not sign the agreement. Inflation of the stock market had projected a higher potential flow of capital, spending, and development. As the market capitalization of commercial banks in the US with exposure to developing-country loans had increased by $\$ 13$ billion, their findings indicated that both lenders and borrowers benefit from debt relief in a situation where the borrowers were affected by debt overhang.

Somasundaram (2020) observed that COVID-19 has had a significant effect on India and most of the industries in India. Banks and non-banking financial firms, in particular, have been more severely impacted. They play a key role in the development of the Indian economy as most of the self-employed people rely on banks or financial institutions to borrow for their business growth. The moratorium facility granted to borrowers of banks and non-banking financial companies by the Reserve Bank of India came with a set of merits and demerits which has been discussed in the paper.

\section{RBI MORATORIUM 2020}

The RBI offered a six-month moratorium between March 1, 2020, and August 31, 2020, on all loan equated monthly instalments. Features of Moratorium 2020 are (RBI circular dated March 27, 2020):

- It was applicable on all loans including education loans, credit card dues, personal loans, home loans etc.

- Borrowers did not have to make the EMI payments on their loans during this period. Individuals whose EMIs on loans were outstanding as of March 1, 2020, could opt for the moratorium.

- It was offered as a means to lessen the burden of debt servicing by the COVID-19 disruptions and ensure the operation of businesses.

- The repayment schedule would be shifted to a period after the moratorium.

- During the moratorium period, interest would continue to accrue on the term loan's outstanding amount.

- All co-operative banks, commercial banks, National Financial Institutions, and NBFCs were allowed to grant a moratorium of three months. The period stated in the initial circular was then extended up to August 31, 2020. This would apply to all term loans including retail, crop and agricultural term loans.

- The rescheduling of payments and interest would not count as a default for reporting to Credit Information Companies (CICs) by the lending institutions. The CICs would ensure that any action taken by a lending institution would not negatively affect the credit history of a borrower who has opted for the moratorium. Additionally, the RBI permitted 
the lenders to allow one-time restructuring for personal loans while maintaining standard asset classification and corporate loans without a change in ownership.

\section{IMPACT AND PREDICTED IMPACT OF THE RBI MORATORIUM}

\section{The State of the Indian Banking Sector (Pre-Covid-19 Period)}

The performance of the banking sector had improved in FY20 with several banks reporting growth in earnings. As per RBI data on sectoral asset quality given in figure 1 (Chapter II RBI circular dated July 24, 2020),

- In July 2020, credit growth of non-food banks at $6.7 \%$ was the same as in June 2020, but lower than the $11.4 \%$ growth in July 2019.

- Credit growth for agriculture and services produces an annual GNPA of $9 \%$ and $13 \%$. In July 2020, credit growth for agriculture increased by $5.4 \%$, compared to a growth of 6.8 $\%$ in July 2019.

- Service sector credit continued to rise at a high rate of $10.1 \%$ in July 2020, compared to $15.2 \%$ in July 2019. Within the services sector, credit to tourism, computer software, and hotel and restaurants resisted the downtrend with higher growth in July 2020 compared to July 2019. The credit growth to the corporate sector constitutes $37 \%$ of the total bank assets and forms $73 \%$ of NPAs.

- The credit growth to the industrial sector was at $0.8 \%$ in July 2020 which was lower as compared to $6.1 \%$ in July 2019. Within the industrial sector, credit growth for food manufacturing, mining \& quarrying, petroleum, coal products \& nuclear fuels, cloth \& cloth products, timber, building, and paper \& paper products increased in July 2020 compared to growth in the previous year's corresponding month.

- Tourism, transportation, sports, hospitality, petroleum, real estate, and food industries have been affected severely due to the pandemic. Pharmaceuticals, FMCG, e-commerce, services, and IT businesses have performed relatively well despite the pandemic. Hence, loans to these sectors are unlikely to turn bad.

- Retail credit accounts for $22 \%$ of overall bank lending and produces $3.7 \%$ of NPAs. Personal loans, home loans and car loans have low delinquency rates.Personal loans have continued to do well, rising by $11.2 \%$ in July 2020, compared to 17\% in July 2019.

- The gross outstanding bank credit was at Rs.91.36 lakh crore in June 2020 compared to Rs.85.47 lakh crore in June 2019. 


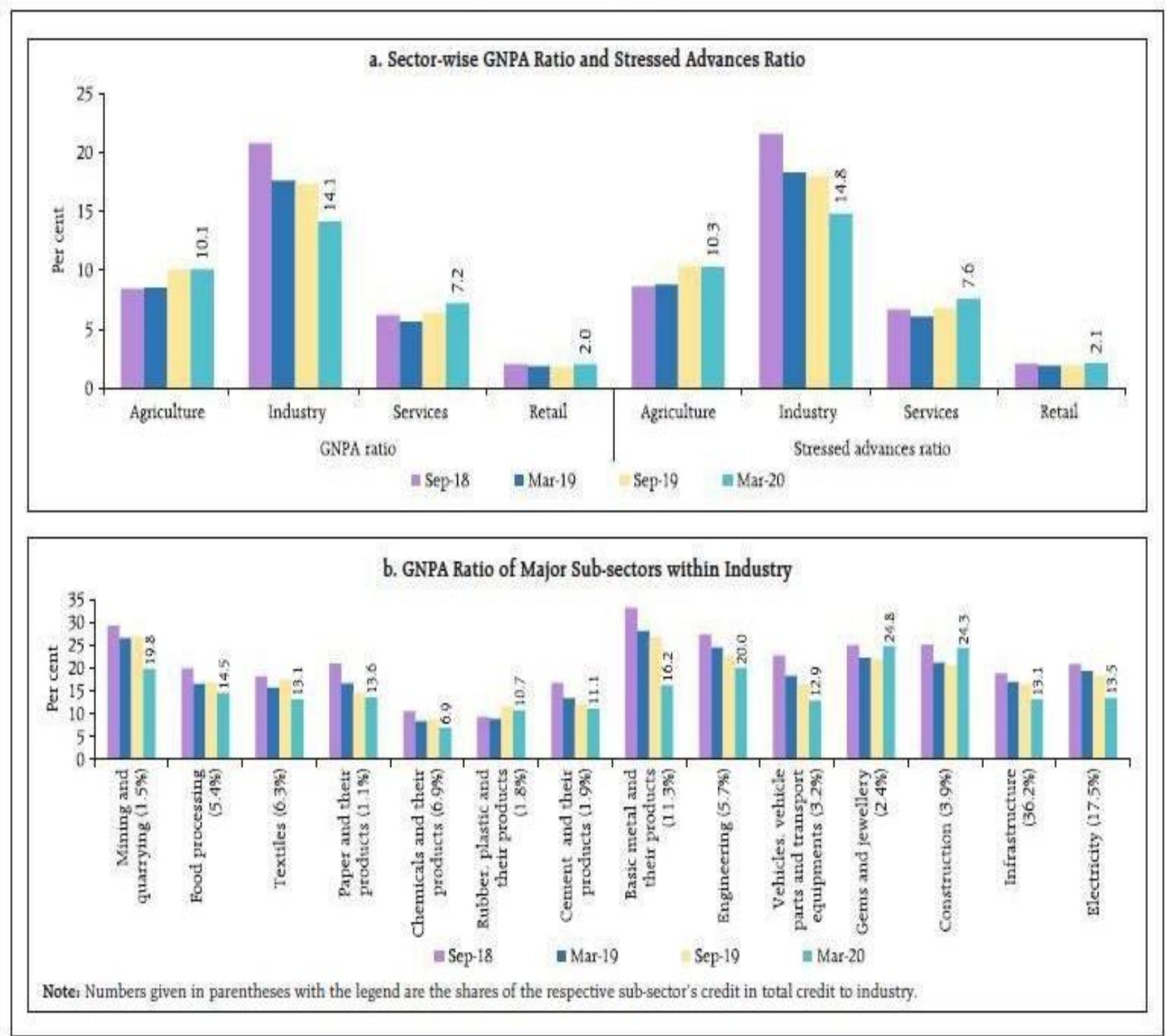

Figure 1. Sectoral Asset Quality Indicators

Source: Chapter II RBI circular dated July 24, 2020

\section{Overview of Bank Performance (During Covid-19)}

Year-on-year Credit growth of Scheduled Commercial Banks, which declined dramatically during the first half of 2019-20, plummeted to $5.9 \%$ by March 2020. It then remained at a standstill until the beginning of June 2020 which can be seen in figure 2. This moderation was prevalent in all banking classes. Deposit development (y-o-y) also declined during 2019-20 second half, primarily due to PVBs (Private Sector Banks), while a recovery occurred in the first few months of 2020-21, indicating the precautionary saving actions of COVID-19. Earnings of commercial banks before taxes and provision (EBPT) were aided by an increase in other operating income (OOI) and moderation in operating expenditure growth. Net interest income (NII) declined slightly, lowering the net interest margin (NIM) to the amount of September 2019. Profitability rates, i.e., the return on equity (RoE) and the return on assets (RoA), decreased in the FY 2019-20 second half for all the different banking classes. 


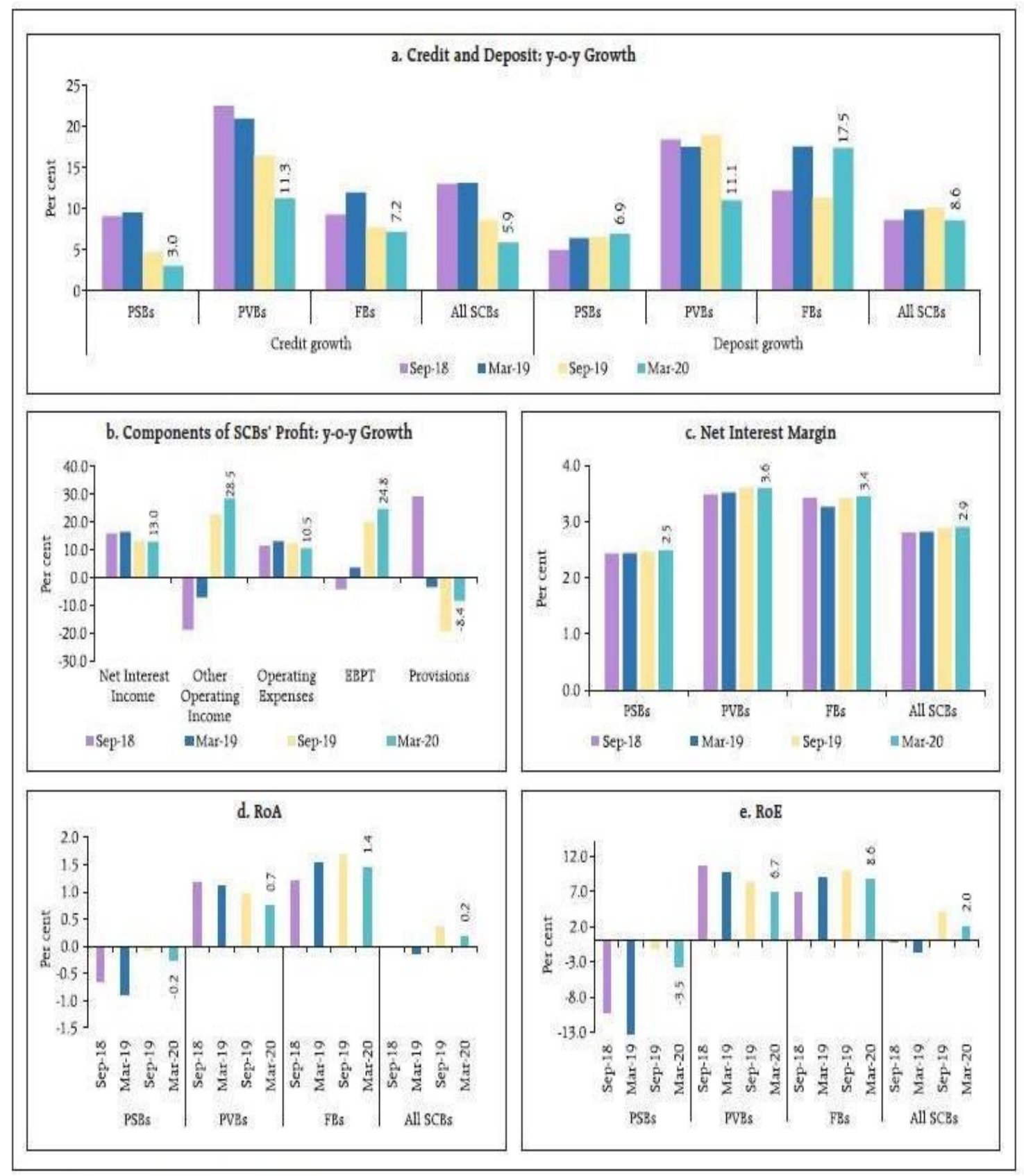

Figure 2. Performance indicators for SCBs

Source: Chapter II RBI circular dated July 24, 2020

\section{Predicted Impact of the Moratorium}

Moratorium-2020 was announced by the RBI as a relief measure during the pandemic. However, the six-month moratorium coupled with the one-time loan restructuring program may put stress on the Indian banking system. The measures may have avoided a spike in NPAs for now but this may not be true for the near future.

- NPAs (Non-Performing Assets) - As per the macro stress tests reported by the RBI in the July 2020 Financial Stability Report, the NPAs may surge to one and a half times above 
the level in March 2020 under the baseline scenario and in a very stressed scenario, the surge could be 1.7 times above the March 2020 levels as shown in figure 4. According to Care Ratings' Analysis of NPA Movement published on October 13, 2020, Gross NPAs ratios of Indian Banks are predicted to be around 11 to $11.5 \%$ by the end of FY21. The banks are likely to restructure $4 \%$ to $5 \%$ of the overall bank credit outstanding. The gross NPA of SCBs was 8.2\% in Q1 FY21 as compared to 9.5\% in Q1 FY20 shown in figure 3. By the end of FY21, the numbers are expected to increase much beyond the $8.5 \%$ level which was seen at the end of FY20 while being moderated by the current write-offs and one-time restructuring scheme. The banks may also face severe stress due to low-rated corporate as personal loans can't be registered under the restructuring scheme.

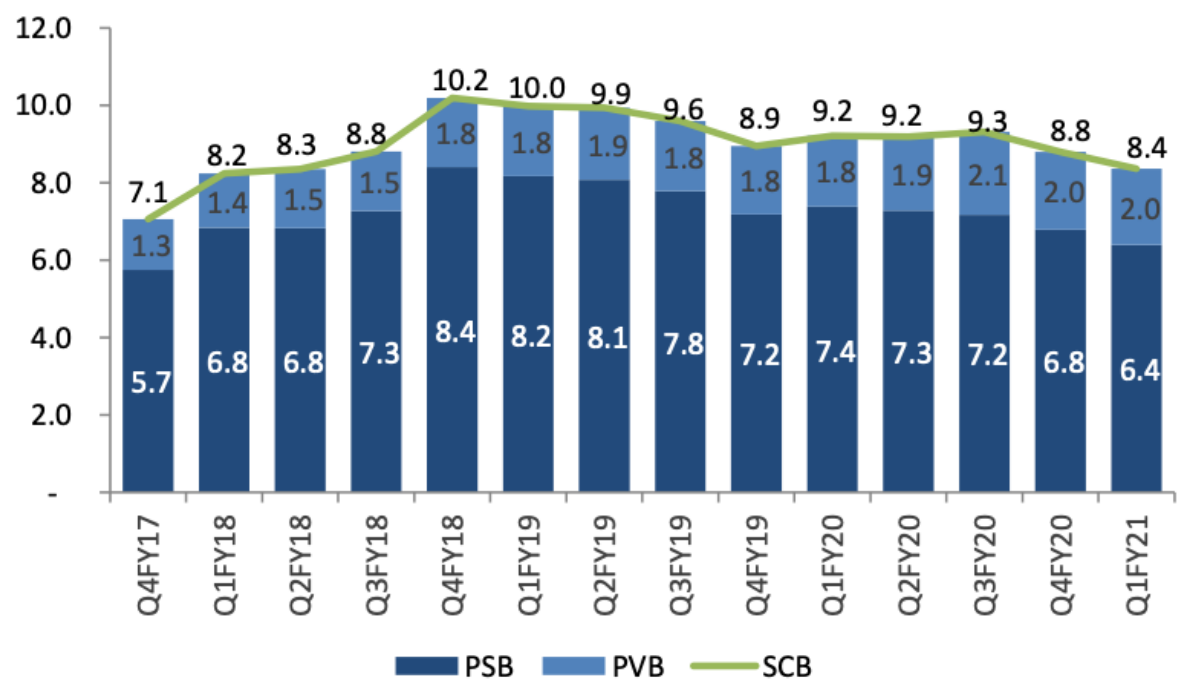

Figure 3. Movement in gross NPA in Rs. Lakh Crore

Source: Analysis of NPA Movement, Care Ratings dated October 12, 2020

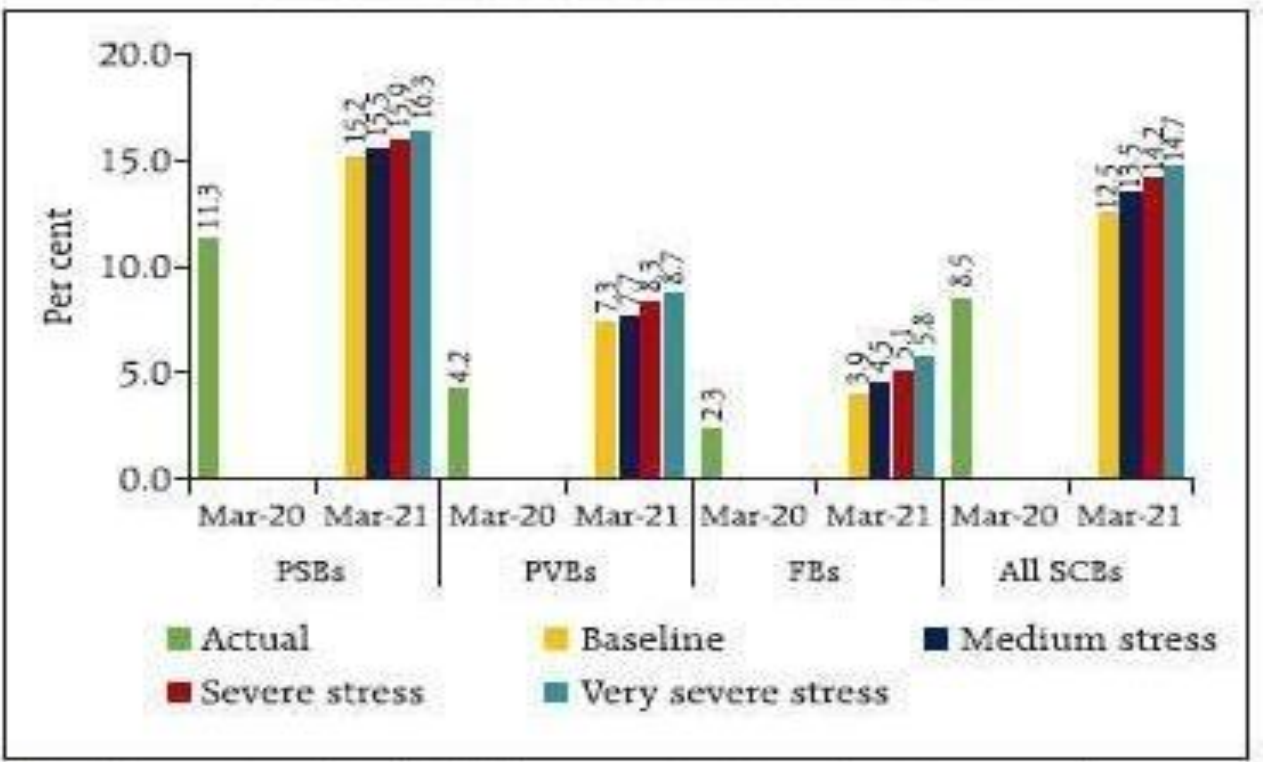

Figure 4. GNPA ratio projections for SCBs

Source: Chapter II RBI circular dated July 24, 2020 
- CRAR (Capital to Risk-Weighted Assets Ratio) -Under the baseline scenario, the RBI predicts the system level CRAR to drop to $13.3 \%$ in March 2021 from the March 2020 level. In the case of a severe stress scenario, the levels could drop to $11.8 \%$ as shown in figure 5. "Although gross and net non-performing asset ratios had come down in March 2020 along with receding slippage ratios, the economic fallout of the pandemic is likely to test this resilience, especially since the regulatory accommodations announced in the wake of the outbreak have masked the consequent build-up of stress," stated by the RBI in its annual 2019-20 report.

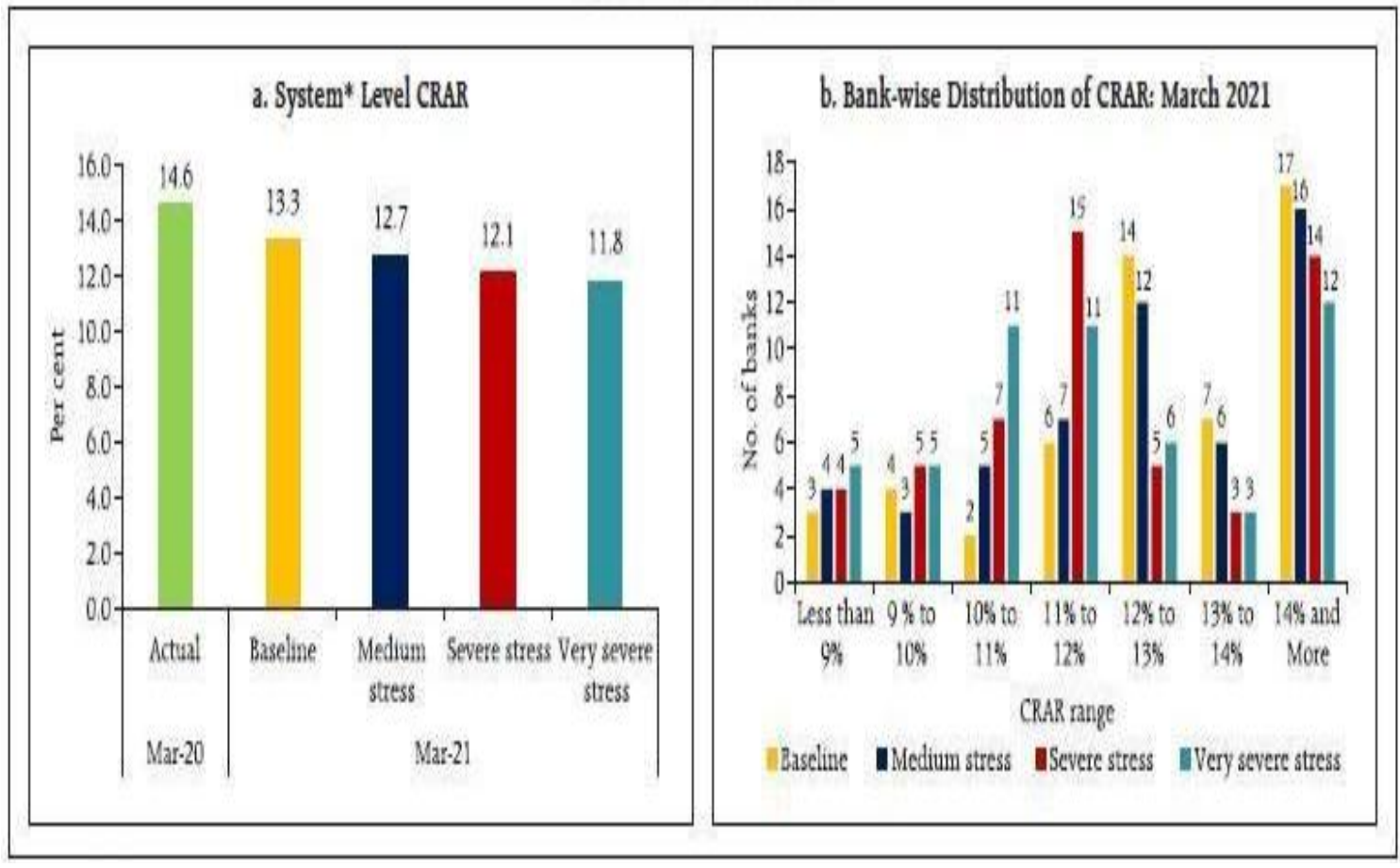

Figure 5. CRAR projections for SCBs

Source: Chapter II RBI circular dated July 24, 2020

- Economic Activity and Bank Credit -The Indian economy has steadily reopened in June 2020 after a national lockdown declared by the government to avoid the curb the number of COVID-19 cases. During this time, the slowdown in the disbursement of new credit was attributed by bankers to difficulties in conducting origination activities, lack of clarification in the extension of the moratorium, and risk aversion amid tell-tale signs of stress throughout sectors. The banks are hopeful with regards to the number of loans that will turn into NPA's as borrowers begin repayments after the end of the moratorium. Economic recovery is expected to be slow which along with the subdued credit growth could lead to the bank's interest income becoming limited. The effects of the extended moratorium could be reflected on the bank's balance sheets for a prolonged period. Additionally, if the rate of growth of deposits becomes roughly twice the rate of growth of credit, the banks may face stress on their balance sheets. If the banks slip into the "pretend and extend" mode, where loans are not recognized as bad assets and the companies, are not taken to bankruptcy courts, the result could be similar as in the past- a 
series of mistakes in which the borrowers with the capacity to repay their loans don't feel the pressure to do so. As per Moody's, Retail and Hotels, Oil \& Gas, Transportation, and Aviation are the industries where the credit shock is most significant. Once the lockdown restrictions have been lifted in economies across Asia including India, the consumer trust would remain, thereby leading to a continued burden on credit quality for those industries. However, the long-term shock of far slower inflation that policy support can't offset would accelerate the debt burden from already high levels.

- Recapitalization -Banks need capital to cope with stress in their books or to expand their ability to lend. If stress levels will be noticeable in the second half of 2020, the need for growth resources will not be much as economic activity will take some time to recover to pre-Covid-19 levels. The government has infused Rs 3.5 trillion in PSBs (Public Sector Banks) over the recent years, with the last round of recapitalization taking place in September 2019, when the government agreed to front-load Rs 70,000 into banks. A majority of the capital infusion has taken place through the issuing of bonds, which do not have an immediate effect on the finances of the government but will become the government's responsibility for interest payments in the years to come. As the government needs to borrow an extra Rs 4.2 trillion against Rs 7.8 trillion currently assigned in the budget, the government's interest burden will also rise as these bonds are up for redemption. The recapitalization of public sector banks is going to be crucial in the situation of likely asset quality pressures on Indian Banks. "Recapitalisation plans for public and private sector banks assume critical importance. The minimum capital requirements, which are calibrated based on historical loss events, may no longer suffice to absorb post-pandemic losses," as per a statement made by the RBI. Additionally, the RBI governor has asked banks to be prepared for a bad loan shock due to COVID by enhancing their capital strength.

- Lending Ability of Banks -Fundamentally, the health of every lending institution depends primarily on its liquidity and income-both of which affect its lending ability. If the moratorium results in high bad loans and low incomes, the stability of the financial institutions would be adversely affected and may lead to a ban on lending in compliance with existing regulatory requirements. With this aspect in mind, the RBI has now authorized a one-time restructuring of loans without classifying them as bad loans, subject to certain criteria (which are yet to be notified). Also, if the borrower is under actual financial hardship, the banks can opt to restructure the loan on more reasonable terms (increased tenure, decreased interest, etc.) against a general deferral of repayments.

- The Profitability of Banks - The loan moratorium could continue to shift the credit environment of the banking sector. Similar changes by different countries across Asia would only help to alleviate credit-negative strains on banks, businesses, and the wider economy. These measures will not completely compensate for credit and economic disruption. The moratorium period would put the payment deadline back by six months for accounts that take the option. Despite the chance of improved credit quality for larger companies through policy support, the profitability of the Indian banking sector will decline. This is mainly due to the lower net interest margins and weakening asset quality. Financial authorities in several Asian economies such as India, China, and Malaysia have 
introduced debt moratoriums to relieve the cash crisis for individuals and companies. A delay in redemption will bring immediate relief to borrowers but these measures will also limit the ability of banks to take constructive recovery and turnaround steps. Due to this, an even larger accumulation of credit-defaults could take place until the moratoriums are lifted.

\section{Interest Waiver and Its Implications for Banks}

On 23 October 2020, the Government declared an Ex-gratia scheme for the exemption from interest-on-interest to offer some relief and financial assistance to borrowers who may face financial difficulty due to COVID-19. Under this, the government would pay for interest incurred on interest levied during the moratorium and not the complete outstanding interest during the period. The incentive applies to all borrowers with any unpaid debt, including credit card fees and housing, school, auto, personal, and consumer loans up to a limit of ₹2 crores as of 29 February 2020. The advantage would be open to those who have not opted for a moratorium. According to the guidelines provided by the Government, the relief would be proportional to the difference between compound interest and basic interest over six months. The calculation would be the same for all borrowers - those who did not apply for a moratorium, those who opted for a six-month moratorium, and those who opted for a moratorium of fewer than six months. It is, however, not eligible on fixed deposit loans and loans that were defaulted on, on or before 29 February.

After crediting the amount, lending institutions will claim the reimbursement from the central governments thereby diminishing the likelihood of any adverse effects on the banking sector. However, for Indian lending institutions with over $\$ 120$ billion of bad loans and the COVID-19 induced collapse in the demand, the waiver will further stress the already severely stressed balance sheets of the banks. Further, the lending institutions will have to recalculate the millions of loans and may also have to wait nine to 24 months to get the funds from the government, increasing the burden on the institutions.

India's Supreme Court is in the process of hearing a PIL (Public Interest Litigation) dispute for the non-waiver of complete interest outstanding during the loan moratorium period. IT was observed that in such times, banks should not only offer moratoriums but also waive the interest. If a judgment of a complete interest waiver is made, there could be a severe impact on the banking sector. If the government overburdens the offer of subsidies to the borrower, and if the result is further weakening the credit system and potential inflation as the government's debt bloats, the price will be paid by all the taxpayers. Banks borrow depositors and lend to businesses and individuals. In any instance, there will be more depositors than creditors. So, any decision to benefit creditors would eventually come from paying less to the depositors which would prioritize the handful over the vast majority of the bank's clients.

It may be a good banking principle to give borrowers a reprieve when they are in desperate need, but it is a moral liability if it is presumed that the borrower must always be accommodated. The financial system as a whole would be at risk where there is an implicit or overt presumption that borrowers need not care about repayment. In this scenario, the borrowers would borrow recklessly. When a bank goes under, the depositors are placed in a precarious position and are sometimes forced to wait for a government bailout to get their deposits back. It creates a structural problem where both depositors and borrowers believe that their decisions of depositing money in or borrowing from a specific bank, are not at risk. There is a stronger 
argument for maintaining the confidence of depositors than the confidence of borrowers, since not only do more of them exist, but they are also vital to the lending industry as a whole.

\section{INSTANCES OF MORATORIUMS AROUND THE WORLD}

\section{United States of America}

From March 2012 to June 2013, the National Mortgage Settlement extended relief to more than 300,000 homeowners who had lost possession of their houses without due process. New Jersey introduced a moratorium in the first half of 2011 when the courts implemented an eight-month moratorium on foreclosures aimed at six mortgage servicers. The lending industry responded to the moratorium proposals with moral hazard projections, concluding that a moratorium would raise the number of delinquencies (Collins\& Urban, 2017).

\section{Greece}

In response to the economic crisis in Greece, the legislature adopted a package of measures to provide relief to over-indebted households in 2010. Specifically, the government enacted a new law on personal bankruptcy that removed primary residences from liquidation. Around the same time, the government had imposed an almost universal moratorium on the foreclosure of primary homes. This new regulatory environment presented homeowners with two choices to secure their primary residence in the event of delinquency; default and apply for debt relief under the new Personal Insolvency Act, or default passively and protect the primary home through a foreclosure moratorium (Artavanis \& Spyridopoulos, 2017).

\section{Thailand}

The Cabinet had approved increased debt relief plans such as suspending monthly loan repayments and interest for three years for farmers impacted by the 2011 floods. The moratorium applied to farmers who had borrowed before the deluge and counted from the first day on which their farmland was struck. The Government compensated for the interest on the loans subject to the moratorium and also approved a budget of 715 million Baht for the 2014 fiscal year to reimburse farmers for interest under the moratorium program (Nuansoi, 2013).

\section{CONCLUSION}

The six-month moratorium offered by the Reserve Bank of India was granted as a relief measure for the borrowers during the COVID-19 pandemic. The use of moratoriums is not new to the Indian banking sector as moratoriums have been granted in multiple instances in the past. Moratoriums have also been used across the world in the form of Debt or Foreclosure moratoriums in countries such as Greece, Thailand, and the USA. In particular, Japan had offered a moratorium for SMEs after the 2008 housing crisis but the effects of the prolonged moratorium period were largely negative and the scheme offering the moratorium was widely considered as a failure.

The Indian banking industry had amassed bad loans of around Rs 9 lakh crores before the impact of COVID-19. The moratorium is expected to cause a surge in the NPAs by the end of the current fiscal year and the RBI predicts the system level CRAR to drop to levels lower than the same period last year. The slow recovery of the economic activity could lead to a decrease in the interest income of banks and a prolonged moratorium period could create additional stress on the banks' balance sheets. To cope with the stress on their books and expand their ability to lend, 
recapitalization is going to be crucial for the banks. If the moratorium results in a large number of bad loans, it will adversely affect the stability and thus the lending ability of the banks. Additionally, India's banking sector's profitability is expected to decline due to weakening asset quality and lower interest margins.

The Government declared an interest-on-interest waiver for the interest incurred on interest levied during the moratorium period. The reimbursement for the amount can be claimed by the lending institutions after it is credited by them, but the scheme is likely to add further stress to the already stressed balance sheets of the banks. Due to the scheme, the banks will have to recalculate millions of loans and may also have to wait up to 24 months to get the funds from the government, thereby increasing their burden. A complete waiver of interest is being disputed in the Supreme Court of India and if permitted, it would lead to severe consequences for the Indian banking sector.

The moratorium offered is going to present numerous challenges to the Indian banking sector in the coming months. Based on the predictions it is evident that the effects on the Indian banking sector are mostly adverse and the performance of the sector will decline as compared to the previous year.

\section{REFERENCES}

Arito, O. (2017). Forgiveness Versus Financing: The determinants and impact of SME debt forbearance in Japan1. RIETI Discussion Paper Series 17-E-086. Retrieved October 10, 2020, from https://www.rieti.go.jp/jp/publications/dp/17e086.pdf

Artavanis, N., \& Spyridopoulos, I. (2017). Foreclosure Moratorium and Strategic Default. EFMA. Retrieved October 14, 2020, from https://www.frbatlanta.org/-/media/docum ents/news/conferences/2017/1201-real-estate-industryforum/papers/Artavanis_Foreclosure_Moratorium_and_Stategic_Default.pdf

Arslanalp, S., \& Henry, P. (2005). Is Debt Relief Efficient?. The Journal of Finance, 60(2), 1017-1051.

Bhargava, K. (2020, April 21). Loan moratorium may haunt banks even after getting lifted; Moody's explains post moratorium credit landscape. Financial Express. Retrieved October 22, 2020, fromhttps://www.financialexpress.com/industry/banking-finance/l oanmoratorium-may-haunt-banks-even-after-getting-lifted-moodys-explains-post-mo ratorium-credit-landscape/1935473/

BFSI Research CARE Ratings. (2020, October 13). Analysis of NPA movement [Circular]. Retrieved October $\quad 15, \quad 2020, \quad$ from https://www.careratings.com/upload/NewsFiles/SplAnalysis/Analysis\%20of\%20NPA\%2 OMovement.pdf

Collins, J.M., \& Urban, C. (2017). The Effects of a Foreclosure Moratorium on Loan Repayment Behaviors. Regional Science and Urban Economics, 68(1), 73-83. https://doi.org/10.1016/j.regsciurbeco.2017.10.010 
Dhanorkar, S. (2020). How taking loan moratorium will impact your future EMIs. The Economic Times. Retrieved October 7, 2020, from https://economictimes.indiatim es.com/wealth/borrow/how-taking-loan-moratorium-will-impact-your-future-emis

Imai, M. (2016). Japan's Regulatory Response to Banking Problems. Research Gate. Retrieved October 12, 2020, from https://www.researchgate.net/publication/322893135

Mukherjee, S., Subramanian, K., \& Tantri, P. (2014). Costs and Benefits of Debt Moratoria: Evidence from a Natural Experiment in India. Indian School of Business Working Paper. Retrieved October 10, 2020, from https://cdn.auckland.ac.nz/assets/facultycon

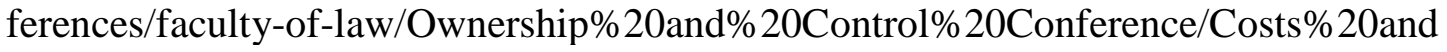
$\%$ 20Benefits $\% 20$ of $\% 20$ Debt $\% 20$ Moratoria\%20Evidence $\% 20$ from $\% 20$ a $\% 20$ Natural $\% 20$ experiment\%20in\%20India,\%20Subramanian.pdf

Nuansoi, W. (2013). The Study on Farmers' Debt, Loan Repayment, and Guideline for Debt Settlement in the South of Thailand. International Journal of Agriculture and Food Science Technology, 4(8), 835-840.

Reserve Bank of India. (2020, March 27). COVID-19 - Regulatory Package [Circular]. Retrieved October 7, 2020, from https://www.rbi.org.in/Scripts/NotificationUser.a spx? Id $=11835 \&$ Mode $=0$

Reserve Bank of India. (2020, August 6). Resolution framework for COVID-19-related stress [Circular].Retrieved October 19, 2020, fromhttps://www.rbi.org.in/Scripts/NotificationUser.aspx?Id=11941\&Mode=0\#: :text=4. ,laid\%20out\%20in\%20this\%20Annex

Reserve Bank of India. (2020, July 24). Chapter II: Financial institutions: Soundness and resilience [Circular].Retrieved October 15, 2020, from https://m.rbi.org.in/scripts/PublicationReportDetails.aspx?ID=1148

Sikdar, A. (2020, September 5). Loan moratorium impact on Indian banks. The Times of India. $\quad$ Retrieved October $\quad 7, \quad 2020$, from https://timesofindia.indiatimes.com/readersblog/anichh-economics/loan-moratoriumimpact-on-indian-banks-25556/

Somasundaram, M. (2020). Merits And Demerits Of Moratorium Offered By Banks And Nonbanking Financial Companies In India. Asia Pacific Journal of Research, 1(1), 23474793.

Sood, J. (2020, March 6). Before Yes Bank, moratorium was imposed on these 8 banks since 1999. Outlook India. Retrieved October 15, 2020, fromhttps://www.outlookindia.com/website/story/business-news-before-yes-bankmoratorium-was-imposed-on-these-8-banks-since-1999/34 8350 
Sinha, S. (2019). As moratorium ends, NPAs may rise in January. The Economic Times. Retrieved October 15, 2020, fromhttps://economictimes.indiatimes.com/industry/ban king/finance/banking/as-moratorium-ends-npas-may-rise-in-january/articleshow/730 39048.cms?

Unnikrishnan, D. (2020, August 26). RBI's annual report: Moratorium, loan restructuring may impact banks' health. Money Control. Retrieved October 20, 2020, fromhttps://www.moneycontrol.com/news/business/economy/rbis-annual-report-moratori um-loan-restructuring-may-impact-banks-health-5752121.html

\section{Copyrights}

Copyright for this article is retained by the author(s), with first publication rights granted to the journal. This is an open-access article distributed under the terms and conditions of the Creative Commons Attribution license (http://creativecommons.org/licenses/by/4.0/) 